\title{
日本における核医学診療の現況（1972年 $)^{\dagger}$
}

\author{
III. 体内投与アイソトープについて
}

筧 弘毅, 三枝健二, 内山 暁

千葉大学医学部放射線医学教空

\section{1. はじめに}

1972年度のわが国における核医学検查機器, および in vitro tests に使用されるアイソトープの現状につ いてはすでに報告 ${ }^{1,2)}$ したが，さらに体内投与アイッ トープについて集計整理した結果を報告する。アイン トープの使用状況についてはすでに1965年と1968年の 2 回アンケート調査が行なわれているが，今回の調査 は1968年の調査からちょらど 4 年経過している。核医 学診療に利用されるアイソトープおよびその化合物の 種類は年々移り変わって招り，その利用傾向も 4 年の 間にかなり変化している。短半減期アイントープの利 用增大はそのよい例の 1 つである。集計内容にはア1 ソトープの体内投与件数, 投与量, 検査の種類などが あり，それぞれについて過去 2 回の結果 ${ }^{3)}$ (表 2, 3; 6,7 ) と比較を行なった。

今回のアンヶート調査はすでに報告している核医学 検査機器および in vitro tests のアンケート調查と同 時に行なったもので，アンケート送付総数は in vivo tests を行なっていると思われる施設461（内訳大学病 院 53，一般病院・その他の施設 408）である。このう ち12月初旬までに回収できた数は 276 (回収率60.0\%) で，これを大学病院と一般病院・その他の施設に分け ると前者は $49(92.5 \%)$, 後者は $227(55.6 \%)$ となる。 これらアンケート回収分のなかには全然無記入のもの 5 ，および研究のみ 1 が含まれており，これらを除く 之有効回答数は 270 (大学病院 49 , 一般病院 - その他 221）である。フンケートには核種および検査目的に 応じて 1 件 1 回の投与量, 最近 1 か月の平均投与件数, および平均投与量の記入を打願いした。

\section{2. アンケート集計結果}

$2 \cdot 1$ 投与件数狖てて

1972年 1 年間の体内投与件数を表 1 に示すが，全件
数は 287,716 件で 1 施設当りの平均投与件数は 1,066 件 /年となる。これを過去 2 回の統計（表 2,3 ）と比較 すると，1965年430件/年，1968年580件/年で， 4 年前 のほぼ 2 倍に增加して括り(図 1)，ここ数年の間に アイソトープ診療が急速に伸展して来たことを示唆す る。さらに，これを診断と治療別にみると，診断件数 $97.6 \%$, 治療件数 $2.4 \%$ で, 診断件数が圧倒的に多く, この傾向は年々高まっている（図2）。一方，治療件 数は1965年の 5,645 件 (227施設), 1968年の 6,726 件 (289施設) に対し，今回は6,935件（270施設）とわず かに增加が認められる程度で, 全体の件数からみると 治療件数と診断件数との比は 4 年前に比べ $1 / 2$ 近く減少 している。次に, 検査・診断に用いられる主な核種あ るいは標識化合物についてみると，やはりまだ ${ }^{131} \mathrm{I}$ が 最も多く, 全件数の半数 ( ${ }^{131} \mathrm{I}$ 無機化合物 $29.4 \%,{ }^{131} \mathrm{I}$ 有機化合物 $21.4 \%$ の計 $50.8 \%$ ）が利用されている。し かし，この利用の割合も1965年の76.7\% (3/4強) から 比べれば25\%以上の減少で, 年々低下の傾向にあるこ とは事実である（図 3)。これを無機と有機の別でみ ると ${ }^{131} \mathrm{I}$ 無機化合物は 1965 年 56\%，1968年 $41.5 \%$ ， 1972 年 30\%と減少の一途をたどっている。また， ${ }^{131} \mathrm{I}$ 有機化合物ではヒップランの利用率は 1965 年 10\%, 1968 年 $11.4 \% ， 1972$ 年 $10.7 \%$ とほとんど変わってい ない。ローズベンガル（抢よび BSP），トリオレイン (およびオレイン酸), その他子件数は少ないが, あまり 変わっていない。MAA, HSA は減少傾向を示してい る(表 4)。 ${ }^{131}$ に次いで使用頻度の高いアイソトープ は ${ }^{198} \mathrm{Au}$-コロイドで，これは過去の統計と同じ順位， すなわち第 2 位にある。その利用率は1965年の $5 \%$,

$\dagger$ Present Status of Nuclear Medicine in Japan (1972) III. On the Radioisotopes Administered to Patients. Hirotake Kakehi, Kenji Saegusa and Guio Uchiyama: Department of Radiology, Chiba University School of Medicine. 


\section{表 1 RI の体内投与件数（1972年）}

Table 1 Number of cases of radioisotope administrations to patients in Japan (1972)

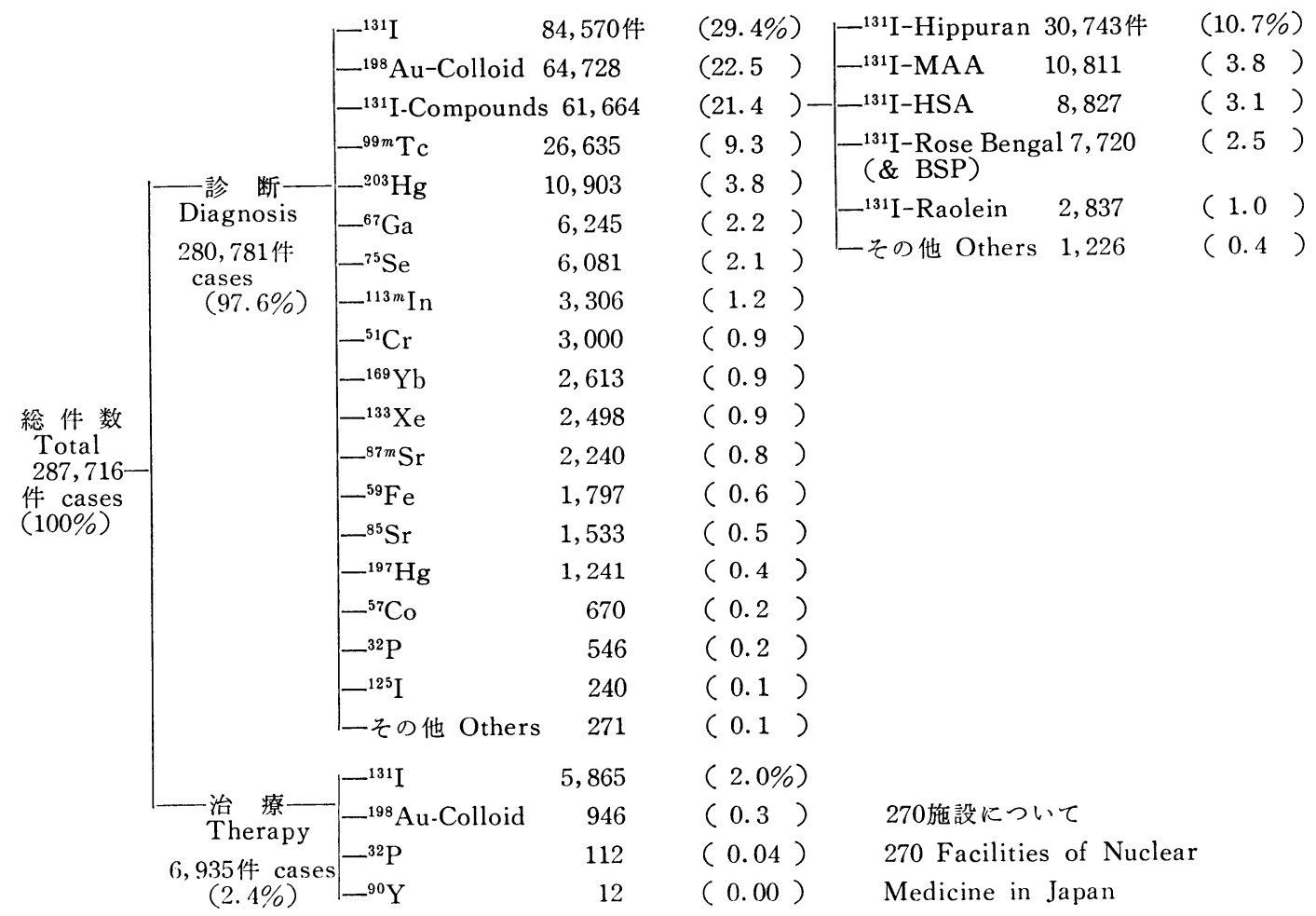

\section{表 2 RI の体内投与件数（1965年）}

Table 2 Number of cases of radioisotope administrations to patients in Japan (1965)

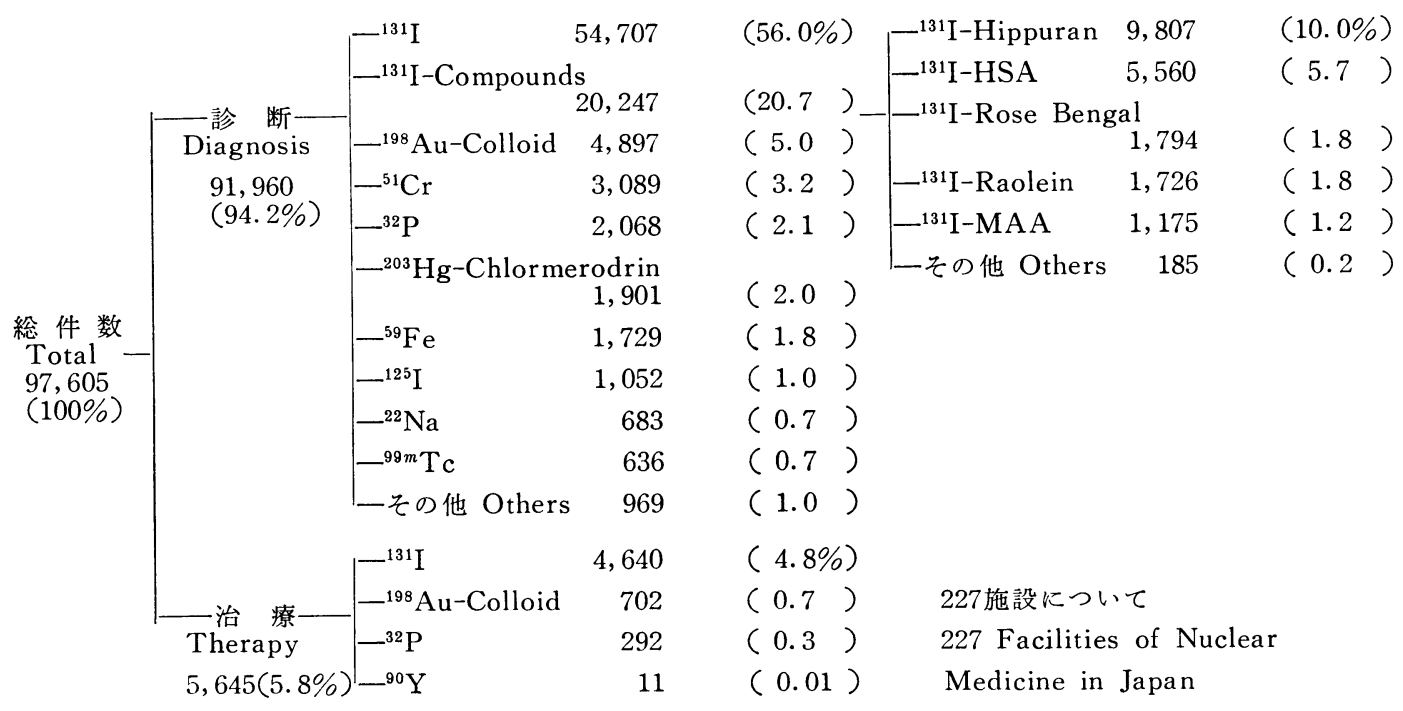




\section{表 3 RI の体内投与件数（1968年）}

Table 3 Number of cases of radioisotope administrations to patients in Japan (1968)
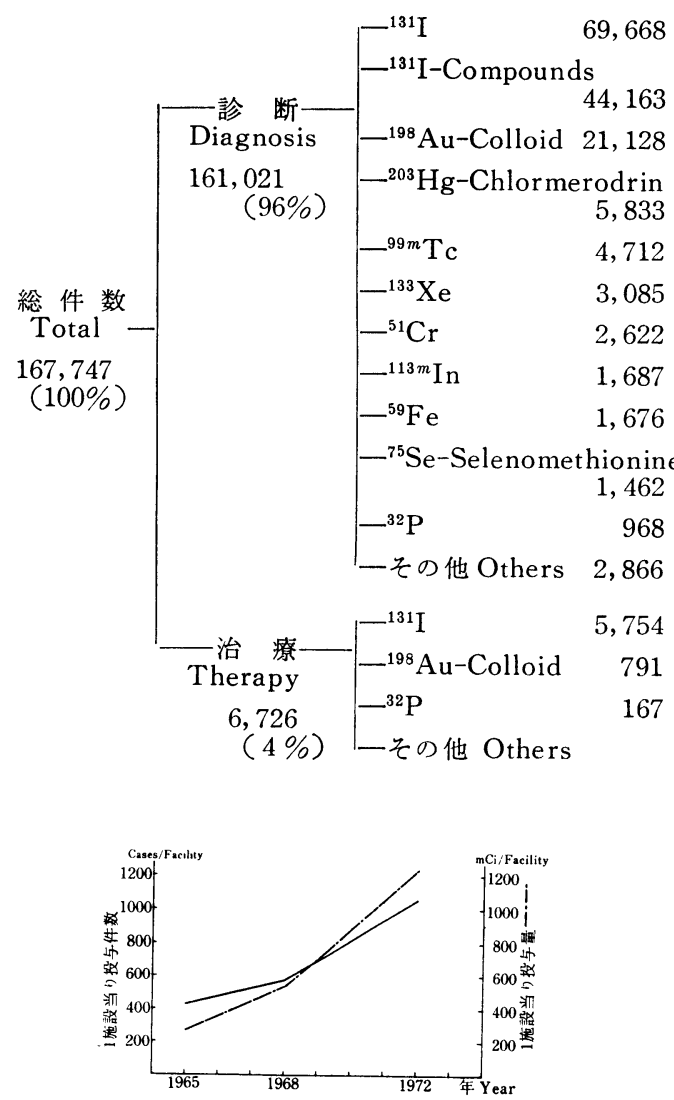

図 11 施設当り平均投与件数, 投与量の 年次的推移

Fig. 1 Chronological changes of the number of cases received radioisotope tests and doses given to patients per facility in Japan.

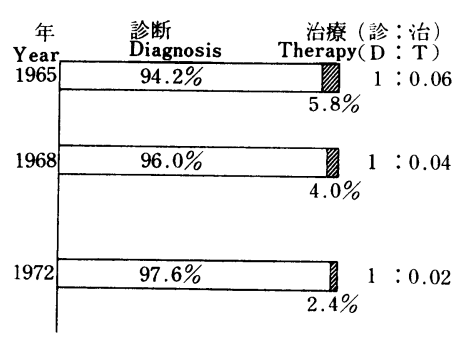

図 2 診断，治療投与件数の年次的推移

Fig. 2 Chronological changes of the number of cases for radioisotope diagnosis and therapy.

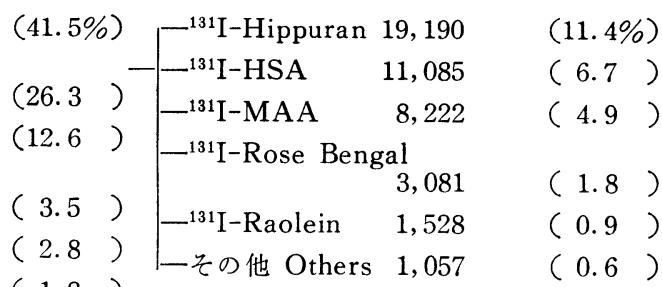

( 1.8$)$

( 1.6$)$

$(1.0)$

(1.0)

$\left(\begin{array}{ll}0.9) \\ (0.6)\end{array}\right.$

$(0.6)$

( 1.7$)$

( $3.4 \%)$

( 0.5$)$ 289施設について

( 0.1$) \quad 289$ Facilities of Nuclear Medicine in Japan

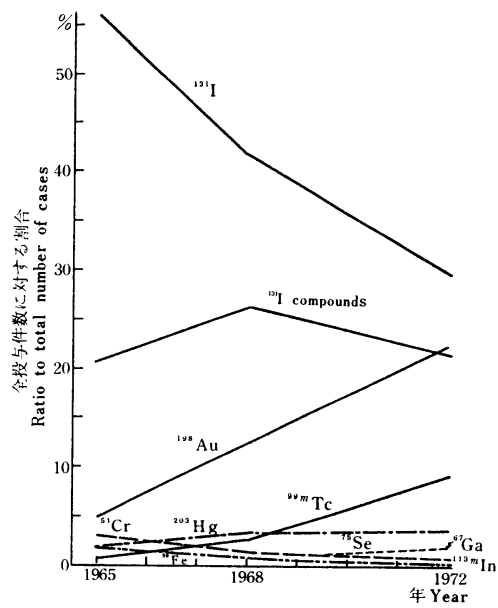

図 $3 \mathrm{RI}$ 投与件数の年次的推移

Fig. 3 Chronological changes of the total number of cases received radioisotope tests.

1968年の $12.6 \%$ に対し, 今回は $22.5 \%$ と増加してい る。この増加は肝シンチグラフィの利用增大によるも のである。第 3 位以下の使用核種は前回調查の結果か らさらに変化し, その順序も大幅に入替わっている (図 3，4)。 ${ }^{131} \mathrm{I},{ }^{198} \mathrm{Au}$ を除く核種については, 1968年に比べ今回は ${ }^{99 m} \mathrm{Tc},{ }^{75} \mathrm{Se}-$ セレノメチオニン, 
表 $4{ }^{131} \mathrm{I}$ 有機化合物使用の年次的推移（百分率）

Table 4 Chronological changes of the number of cases and doses for ${ }^{131}$ I organic compounds administered to patients

\begin{tabular}{|c|c|c|c|c|c|c|}
\hline \multirow{2}{*}{${ }^{131} \mathrm{I}$} & \multicolumn{2}{|c|}{$\begin{array}{llll}1 & 9 & 7 & 2\end{array}$} & \multicolumn{2}{|c|}{1968} & \multicolumn{2}{|c|}{1965} \\
\hline & $\begin{array}{c}\text { 投与件数 } \\
\text { Cases }\end{array}$ & $\begin{array}{c}\text { 投 与 量 } \\
\text { Doses }\end{array}$ & $\begin{array}{c}\text { 投与件数 } \\
\text { Cases }\end{array}$ & $\begin{array}{c}\text { 投 与 量 } \\
\text { Doses }\end{array}$ & $\begin{array}{c}\text { 投与件数 } \\
\text { Cases }\end{array}$ & $\begin{array}{c}\text { 投与量 } \\
\text { Doses }\end{array}$ \\
\hline Hippuran & $10.7 \%$ & $0.4 \%$ & $11.4 \%$ & $0.4 \%$ & $10.0 \%$ & $0.5 \%$ \\
\hline MAA & 3.8 & 0.8 & 4.9 & 1.4 & 1.2 & 0.3 \\
\hline HSA & 3.1 & 0.3 & 6.7 & 0.6 & 5.7 & 0.5 \\
\hline Rose Bengal \& BSP & 2.5 & 0.5 & 1.8 & 0.2 & 1.8 & 0.2 \\
\hline Triolein \& Oleic Acid & 1.0 & 0.1 & 0.9 & 0.1 & 1.8 & 0.3 \\
\hline その他 Others & 0.4 & 0.04 & 0.6 & 0.1 & 0.2 & 0.04 \\
\hline 計 Total & 21.4 & 2.2 & 26.3 & 2.8 & 20.7 & 1.8 \\
\hline
\end{tabular}

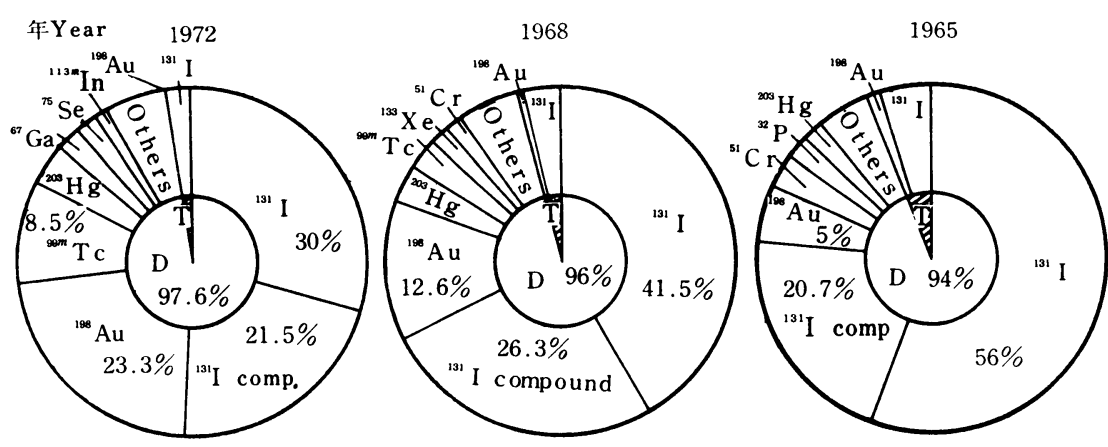

総件数 Total:

287,716 件 cases (270施設 Facilities)

167,747 件 cases (289施設 Facilities)
97, 605件 cases

(227施設 Facilities)

D: 診断 Diagnosis, $\mathrm{T}$ : 治療 Therapy

図 4 年次別 RI 投与件数の百分率

Fig. 4 Chronological changes of the total number of cases received radioisotope tests and treatments.

${ }^{67} \mathrm{Ga}$-クエン酸ガリウムの利用増加が目立つ。逆に, ${ }^{133} \mathrm{Xe},{ }^{51} \mathrm{Cr}$ は減少傾向を示し, ${ }^{203} \mathrm{Hg},{ }^{113 m} \mathrm{In}$ などは あまり変わっていない(図 4 )。

\section{$2 \cdot 2$ 投与量について}

体内投与量については表 5 に示すとおり1972年 1 年 間の総投与量は335, $167 \mathrm{mCi}(270$ 施設) で，1 施設当 りに換算すると平均 $1,240 \mathrm{~m} \mathrm{Ci} /$ 年となる。これは1968 年に比べ2.3倍で，1965年（表6）から1968年（表 7) の過去 3 年間での 2 倍増に比べやや増加しているが, 投与件数 ( $84 \%$ 増), 後述の短半減期アイソトープ使 用増加の割には伸び率は少ない（図 1 )。診断と治療 の別では診断に使用されるアイントープ量の割合は
1965年19.4\%，1968年 $47.9 \% ， 今$ 回 $73.2 \%$ と年々増加 している。逆に，治療に使用されるアィントープ量は ほとんど増加しておらず，全体に対する治療のしめる 割合は年々減少の一途をたどっている。すなわち，診 断と治療に使用されるアイソトープ量の比率は1965年 $19.4 \%: 80.6 \%$ (約 $1: 4$ ), 1968年 $47.9 \%: 52.1 \%$ (約 $1: 1)$ に対し,今回は73.2\%:26.8\%(約1:0.4) とい う結果で (図 5 )，診断に用いられるアイソトープは 量的にも治療をかなり上まわっている。診断に用いら れる主な核種の量的比率の年次的推移を図 6 に示す。 4 年前の1968年には ${ }^{99 m} \mathrm{Tc}(22.9 \%),{ }^{113 m} \operatorname{In}(8.1 \%)$, ${ }^{198} \mathrm{Au}$-コロイド (4.4\%) の 3 核種で約 $35 \%$ に過ぎな かったのに対し，今回の統計では ${ }^{99 m} \mathrm{Tc}(47.9 \%)$, 


\section{表 5 RI の体内投与量（1972年）}

Table 5 Radioisotope doses administered to patients (1972)

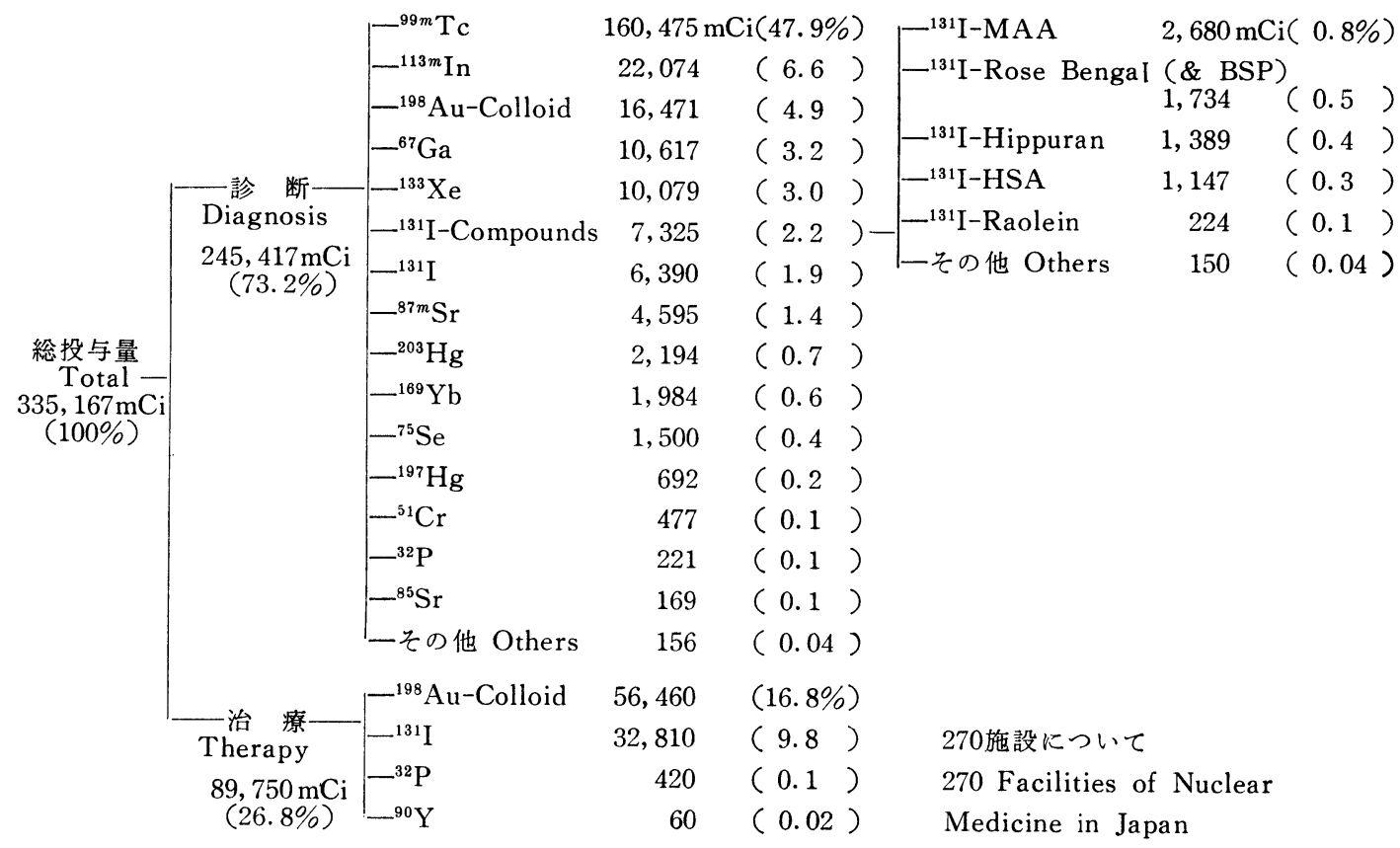

表 6 RI の 体 内投 与 量 (1965年)

Table 6 Radioisotope doses administered to patients (1965)

\begin{tabular}{|c|c|c|c|c|c|c|c|c|}
\hline & & $-{ }^{131} \mathrm{I}$ & $4,197 \mathrm{r}$ & $\mathrm{i}(6.8 \%$ & & ${ }^{131} \mathrm{I}-\mathrm{HSA}$ & & $\mathrm{i}(0.5 \%)$ \\
\hline & 一詮 & $-{ }^{198} \mathrm{Au}$-Colloid & 3,311 & $(5.4$ & ) & ${ }^{131} \mathrm{I}-\mathrm{Hippuran}$ & 292 & $(0.5$ \\
\hline & Diagnosis & ${ }^{99 m} \mathrm{Tc}$ & 1,224 & $(2.0$ & & $-{ }^{131} I-$ Raolein & 178 & $(0.3)$ \\
\hline & $\begin{array}{r}11,924 \mathrm{mCi} \\
(19.4 \%)\end{array}$ & - ${ }^{131} \mathrm{I}-\mathrm{Compounds}$ & 1,116 & $(1.8$ & )- & $-{ }^{131} \mathrm{I}-\mathrm{MAA}$ & 157 & $(0.3)$ \\
\hline & & $-{ }^{32} \mathrm{P}$ & 771 & ( 1.3 & ) & - ${ }^{131}$ I-Rose Bengal & 130 & $(0.2)$ \\
\hline 総投与量 & & $-{ }^{203} \mathrm{Hg}-\mathrm{Chlormer}$ & $\mathrm{drin}_{436}$ & $(0.7$ & & 一その他 Others & 25 & $(0.04)$ \\
\hline $61,529 \mathrm{mCi}$ & & $-{ }^{133} \mathrm{Xe}$ & 378 & $(0.6$ & ) & & & \\
\hline$(100 \%)$ & & $-{ }^{51} \mathrm{Cr}$ & 117 & $(0.2$ & ) & & & \\
\hline & & 一その他 Others & 374 & $(0.6$ & ) & & & \\
\hline & & $-{ }^{131} \mathrm{I}$ & $28,546 \mathrm{n}$ & $\mathrm{i}(46.4 \%$ & & & & \\
\hline & $\begin{array}{l}\text { 一治 療— } \\
\text { Therapy }\end{array}$ & $-{ }^{198} \mathrm{Au}-\mathrm{Colloid}$ & 19,719 & $(32.0$ & ) & & & \\
\hline & $49,605 \mathrm{mCi}$ & $-{ }^{32} \mathrm{P}$ & 870 & $(1.4$ & ) & 227 Facilities of & & \\
\hline & $(80.6 \%)$ & $-^{90} \mathrm{Y}$ & 470 & $(0.8$ & ) & Medicine in Jap & & \\
\hline
\end{tabular}


表 7 RI の 体 内投 与 量 (1968年)

Table 7 Radioisotope doses administered to patients (1968)
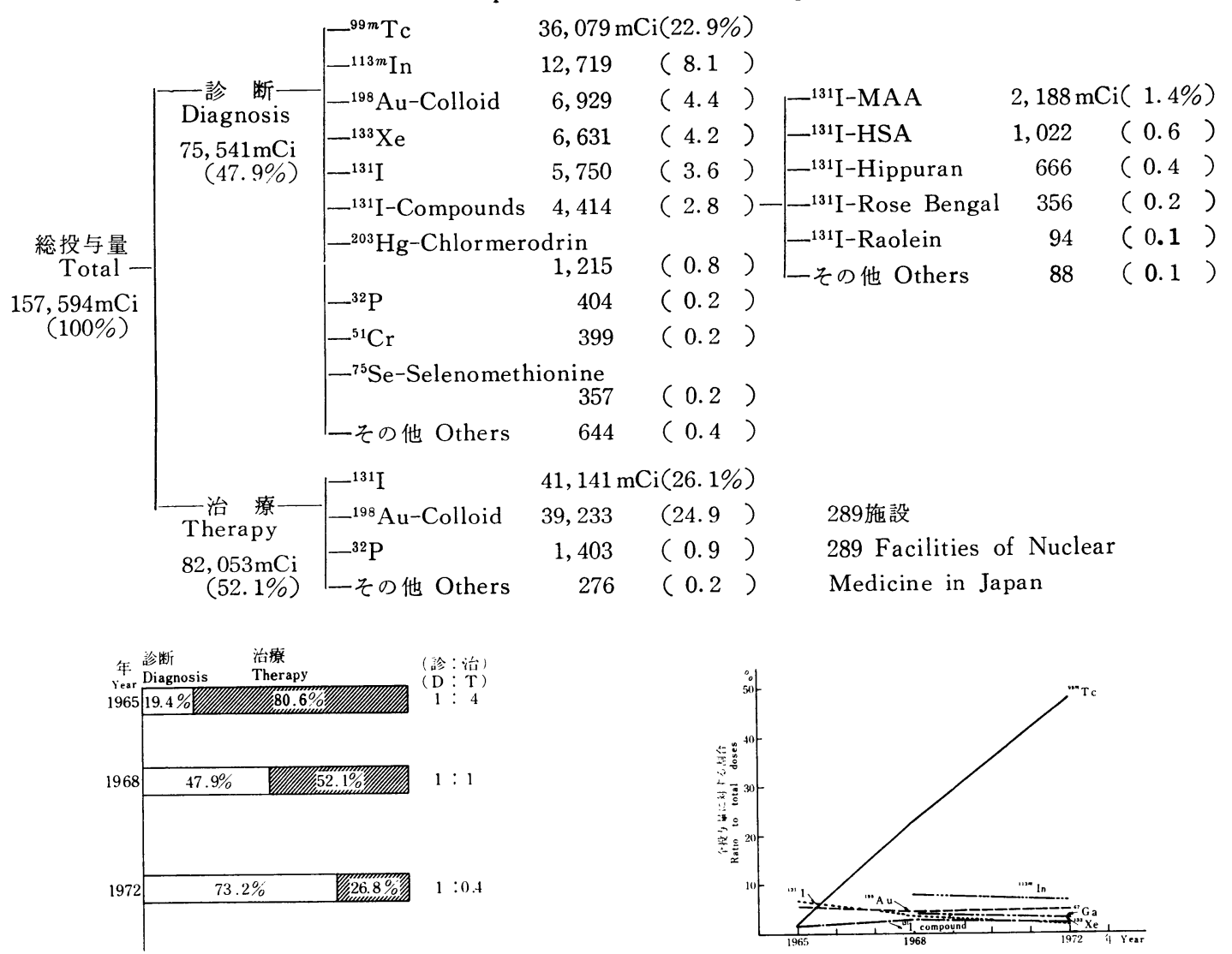

図 5 診断, 治療に用いられた投与量の 年次的推移

Fig. 5 Chronological changes of radioisotope doses given to patients for diagnosis and therapy.

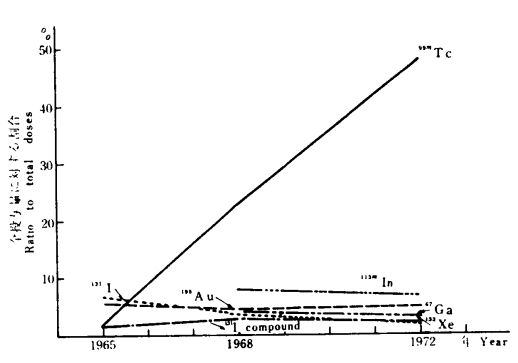

図 7 RI 投与量の年次的推移

Fig. 7 Chronological changes of the total doses of each radioisotope administered to patients for tests.

年 Year 1972

1968

1965
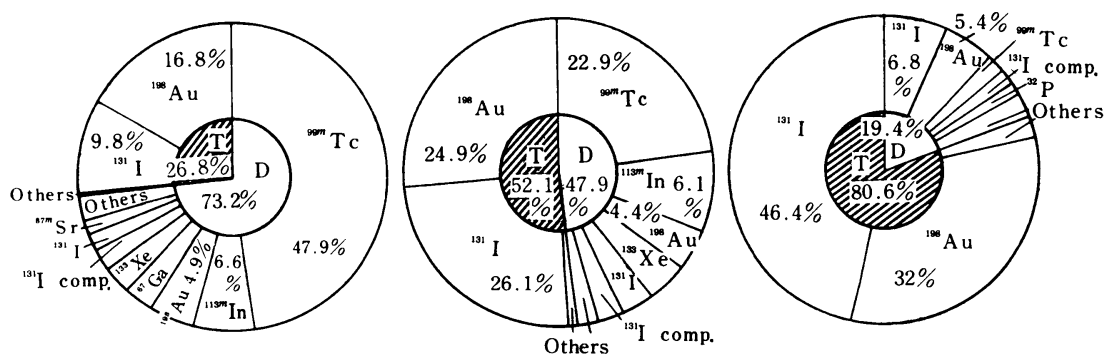

総投与量 Total:

$\begin{array}{ll}335,167 \mathrm{mCi} & 157,594 \mathrm{mCi} \\ \left(270 \text { 施 }^{2} \text { Facilities }\right) & (289 \text { 施設 Facilities }) \\ \text { D: 診断 Diagnosis, } & \mathrm{T}: \text { 治療 Therapy }\end{array}$

$61,529 \mathrm{mCi}$

(227施設 Facilities)

図 6 年次別 $\mathrm{RI}$ 投与量の百分率

Fig. 6 Chronological changes of the total dose of radioisotopes administered to patients for tests and treatments. 
${ }^{113 m} \operatorname{In}(6.6 \%),{ }^{198} \mathrm{Au}$-コロイド (4.9\%)の 3 核種で 約 $60 \%$ と過半数をしめて扣り，なかでも ${ }^{99 m} \mathrm{Tc}$ が50\% 近く使用されていることが大きな特色である（図 7 )。 一方， ${ }^{131} \mathrm{I}$ の使用量はわずかずつ増加しているが，全 使用量に対する割合は年々減少の傾向を示している。 このことは短半減期核種 ${ }^{99 m} \mathrm{~T} \mathrm{c}$ が ${ }^{131} \mathrm{I}$ に置替わって利 用されて来たことを示している。 ${ }^{131} \mathrm{I}$ 標識化合物では ローズベンガル（拉よび BSP），ヒップランを除いて 全体に対する使用量の割合はいずれも減少傾向にある (表 4)。

\section{$2 \cdot 3$ 各種アイソトープの使用内訳}

各診療施設で使用されているアイソトープの種類, 量はその施設の規模によって大いに異なり，詳細に記 述することはもずかしい。記入のあった範囲内で各検 查・治療目的に対する使用施設数, 最小・最大および 平均の 1 回投与量, 施設当りの 1 か月平均検査件数, 1 か月平均投与量をまとめてみた。表 $8 ， 9$ に大学病 院拉よび一般病院・その他の施設に分けて集計した 結果を示す。これらの結果は検査（治療）の種類ごと に投与量, 件数が明確に記入されているものだけに限 り，核種の化学形ごとに 2 種類以上の検査 (治療) を 含めて記入してあるものは除いたので，実際の使用施 設数はこの表に示してある数よりやや多い。表 8 (検 查）には36種のアイソトープ，表 9 (治療) には 3 種 のアイソトープをそれぞれ挙げてある。これら以外に ${ }^{45} \mathrm{Ca},{ }^{86} \mathrm{Rb},{ }^{111} \mathrm{In},{ }^{125} \mathrm{I}$ の 4 核種の記入があったが，各 1 施設だけなので除いた。また，検査項目として62， 治療項目として 5 通り挙げてあるが，特殊と思われる 検査（ 1 施設のみの記入）はやはり除いてある。これ らの表から，わが国の比較的多くの施設（過半数の施 設）で行なわれているアイソトープ検査を挙げると

1） ${ }^{198} \mathrm{Au}$-コロイドによる肝シンチグラフィ（231 施設, $85.6 \%$ )

2） ${ }^{131} \mathrm{I}$-ヨウ化ナトリウムによる甲状腺機能検査 （摂取率測定とシンチグラフィを同時に行なって いる施設191，70.7\%)

3） ${ }^{131}$ I-MAA による肺シンチグラフィ（165施設, $61.6 \%)$

4） ${ }^{203} \mathrm{Hg}$-クロルメロドリンによる腎シンチグラフ 1 (163施設, $60.4 \%)$

5） ${ }^{131} \mathrm{I}$-馬尿酸塩によるレノグラフィ（159 施設, $58.9 \%$ )

6） ${ }^{75} \mathrm{Se}$-セレノメチオニンによる膵シンチグラフ $1(145$ 施設, $53.7 \%$ )
7） ${ }^{99 n} \mathrm{Tc}$-過テクネチウム酸塩による脳シンチグ ラフィ(143施設，53\%)

以上の 7 種で，これらはいずれも日常診療に欠かせぬ 確立された検査となっている。また，全体の20〜30\% の施設で行なっているアイソトープ検査では

1） ${ }^{131} \mathrm{I}-\mathrm{BSP}$ による肝・胆のうシンチグラフィ(79 施設, $29.3 \%$ )

2) ${ }^{67} \mathrm{Ga}$-クエン酸ガリウムによるがんの診断（78 施設, $28.9 \%$ )

3） ${ }^{131} \mathrm{I}$-ローズベンガルによる肝・胆のらシンチグ ラフィ（75施設，27.8\%)

4） ${ }^{203} \mathrm{Hg}-\mathrm{MHP}$ による脾シンチグラフ ィ（69 施 設，25.6\%)

5） ${ }^{85} \mathrm{Sr}$-塩化ストロンチウムによる骨腫瘍の診断 (60施設，22.2\%)

6） ${ }^{51} \mathrm{Cr}$ ークロム酸ナトリウムによる赤血球寿命検 査（58施設，21.5\%)

7） ${ }^{131} \mathrm{I}$-トリオンインによる中性脂肪吸収試験（56 施設， 20.7\%)

以上の 7 種が挙げられる。しかし半数以上の検査, す なわち ${ }^{51} \mathrm{Cr}$ ークロム酸ナトリウムによる脾シンチグラ フィ， ${ }^{59} \mathrm{Fe}$-塩化鉄による血漿鉄 クリアランス試験括

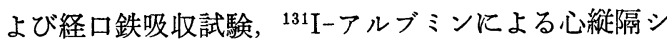
ンチグラフィなど38種の検査はいずれも全施設の $10 \%$ 未満に打いてしか利用されて扣らず，これらは現状で はまだ普及しているとは見なされない。一方治療目的 ではやはり古くから使用されている ${ }^{131} \mathrm{I}-ヨ ウ$ 化ナト リウムによる甲状腺機能六進症の治療が半数近くの施 設(116施設，43\%) で行なわれており，次いで ${ }^{198} \mathrm{Au}-$ コロイドによるがん性漿膜炎の治療(61施設，22.6\%) が挙げられる。その他の治療はごくわずかの施設に限 られている。次に，1回の検査で患者に投与されるア イソトープ投与量をみると，施設によってまちまちで かなりの幅が認められた。これは患者, 検査目的の内 容により，また検査機器，検査技術の違いなどにより 異なるので一概には決め難いが，必要以上に投与量を 増すことは被曝線量の観点から避けるべきである。た とえ短半減期アイソトープであってもむやみに増量す ることは避けるべきである。表 $8 ， 9$ に最小，最大と 平均の各 1 回投与量を示してあるが， ${ }^{99 m} \mathrm{Tc}$-過テクネ チウム酸塩による循環動態シンチグラフィに最大 30 $\mathrm{mCi}$ を投与する施設があったが，これなどは過大投 与と考えられる。1 回投与量の平均值は 1 か月当り の件数, 投与量から算出した結果であるが, 最小値と 最大值でかなり差のある検査も平均値としてみた場合 


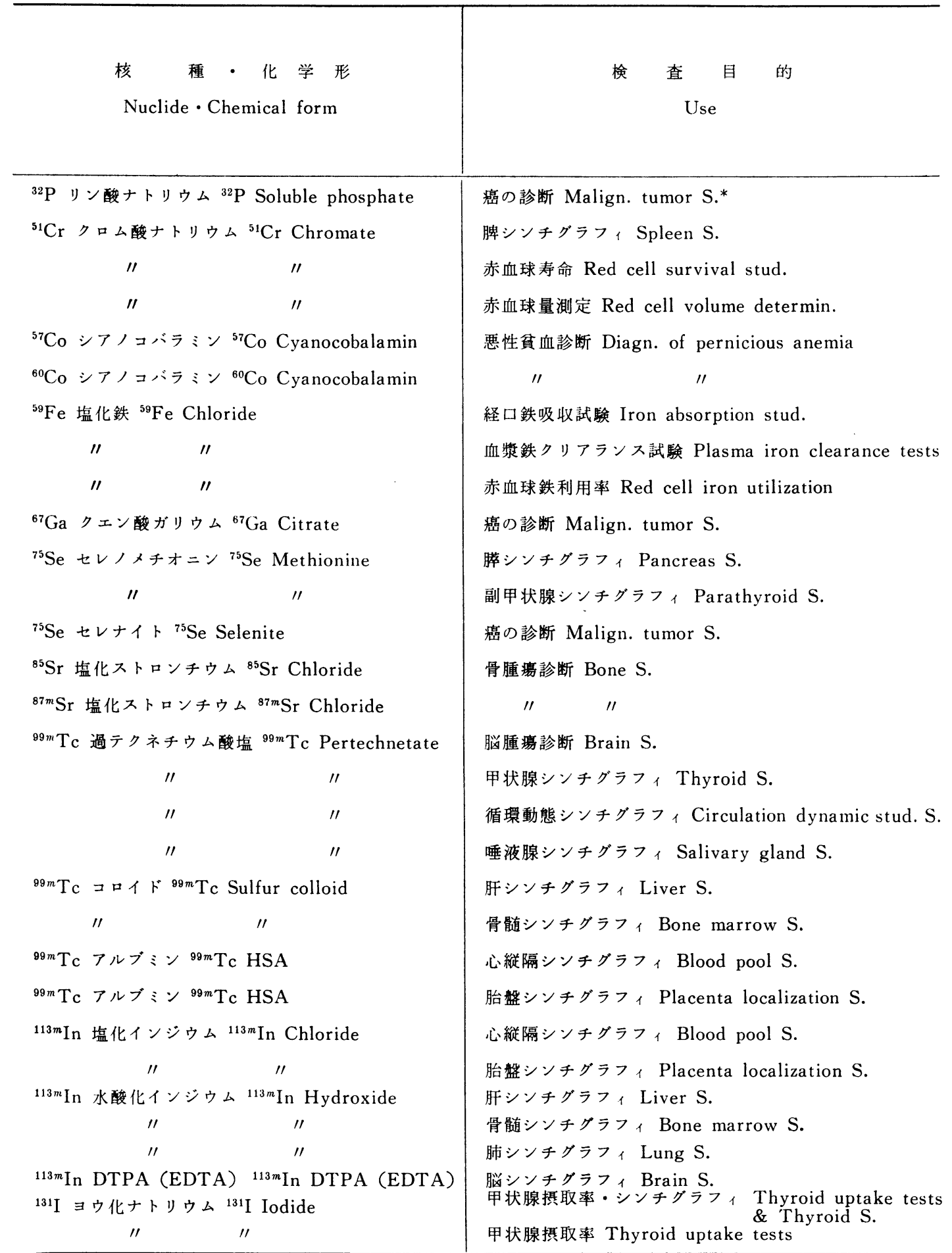

* S: Scintigraphy 
の使用内訳 (検査)

applications used for tests

\begin{tabular}{|c|c|c|c|c|c|c|c|c|c|c|c|}
\hline \multicolumn{3}{|c|}{$\begin{array}{l}\text { 使 用 施 設 数 } \\
\text { Number of Facil. }\end{array}$} & \multicolumn{3}{|c|}{$\begin{array}{c}1 \text { 回投与量 }(\mu \mathrm{Ci}, \mathrm{mCi}) \\
\text { Administ'd doses/case }\end{array}$} & \multicolumn{3}{|c|}{$\begin{array}{l}1 \text { か月平均投与件数/施設 } \\
\text { Number of cases/Facil. } \\
\text { month }\end{array}$} & \multicolumn{3}{|c|}{$\begin{array}{l}1 \text { 出月平均投与量/施設 } \\
\text { Administ'd doses/ } \\
\text { Facil. • month }\end{array}$} \\
\hline $\begin{array}{c}\text { 大学病院 } \\
\text { Univ. } \\
\text { Hosp. }\end{array}$ & $\left|\begin{array}{c}\text { 一般病院 } \\
\text { そ } 9 \text { 他 } \\
\text { Gen. } \\
\text { Hosp. \& } \\
\text { Other }\end{array}\right|$ & $\begin{array}{l}\text { 全 体 } \\
\text { Total }\end{array}$ & $\begin{array}{l}\text { 最 小 } \\
\text { Min. }\end{array}$ & $\begin{array}{l}\text { 最 大 } \\
\mathrm{Max} \text {. }\end{array}$ & $\begin{array}{l}\text { 平均 } \\
\text { Mean }\end{array}$ & $\begin{array}{l}\text { 大学病院 } \\
\text { Univ. } \\
\text { Hosp. }\end{array}$ & $\mid \begin{array}{c}\text { 一般病院 } \\
\text { そ } 9 \text { 他 } \\
\text { Gen. } \\
\text { Hosp. \& } \\
\text { Other }\end{array}$ & $\begin{array}{l}\text { 全 } \text { 体 } \\
\text { Total }\end{array}$ & $\begin{array}{l}\text { 大学病院 } \\
\text { Univ. } \\
\text { Hosp. }\end{array}$ & \begin{tabular}{|c} 
一般病院 \\
の 他 \\
Gen. \\
Hosp. \& \\
Other
\end{tabular} & $\begin{array}{l}\text { 全 体 } \\
\text { Total }\end{array}$ \\
\hline 7 & 4 & 11 & $100 \mu \mathrm{Ci}$ & $1.5 \mathrm{mCi}$ & $405 \mu \mathrm{Ci}$ & 4.3 & 4.9 & 4.5 & $1.53 \mathrm{mCi}$ & $2.30 \mathrm{mCi}$ & $1.84 \mathrm{mCi}$ \\
\hline 9 & 15 & 24 & $100 \prime \prime$ & $0.5 \prime \prime$ & $241 \prime \prime$ & 3.0 & 1.5 & 2.0 & $0.63 \quad \prime \prime$ & $0.41 \quad \prime \prime$ & $0.49 \quad \prime \prime$ \\
\hline 28 & 30 & 58 & $10 \prime \prime$ & $0.3 \prime \prime$ & $142 \prime \prime$ & 3.2 & 1.2 & 2.2 & $0.48 \quad \prime \prime$ & $0.16 \prime \prime$ & $0.31 \prime \prime$ \\
\hline 5 & 7 & 12 & $30 \prime \prime$ & $0.25 \quad \prime \prime$ & $122 \prime \prime$ & 5.8 & 1.0 & 3.5 & $0.68 \quad \prime \prime$ & $0.26 \quad \prime \prime$ & $0.43 \quad \prime \prime$ \\
\hline 22 & 21 & 43 & $0.5 \prime \prime$ & $50 \mu \mathrm{Ci}$ & 1.3 & 1.9 & 1.0 & 1.5 & $3 \mu \mathrm{Ci}$ & $0.6 \mu \mathrm{Ci}$ & $1.9 \mu \mathrm{Ci}$ \\
\hline 3 & 3 & 6 & $0.5 \prime \prime$ & $0.5 \prime \prime$ & $0.5 \prime \prime$ & 4.0 & 2.2 & 2.6 & $2 \prime \prime$ & $1.1 \prime \prime$ & $1.3 \prime \prime$ \\
\hline 14 & 4 & 18 & $1 \prime \prime$ & $250 \prime \prime$ & $26 \prime \prime$ & 2.0 & 1.0 & 1.8 & $55 \prime \prime$ & $10 \prime \prime$ & $47 \prime \prime$ \\
\hline 12 & 9 & 21 & $4 \prime \prime$ & $20 \prime \prime$ & $13 \prime \prime$ & 2.6 & 1.8 & 2.3 & $34 \prime \prime$ & $23 \prime \prime$ & $30 \prime \prime$ \\
\hline 8 & 7 & 15 & $5 \prime \prime$ & $100 \prime \prime$ & $23 \prime \prime$ & 2.4 & 2.2 & 2.3 & $28 \prime \prime$ & $81 \prime \prime$ & $53 \mathrm{mCi}$ \\
\hline 34 & 44 & 78 & $500 \prime \prime$ & $3 \mathrm{mCi}$ & $1.7 \mathrm{mCi}$ & 9.4 & 5.0 & 6.9 & 15.81 & 8. $65 \mathrm{mCi}$ & 11.80 \\
\hline 43 & 102 & 145 & $100 \prime \prime$ & $0.5 \prime \prime$ & $248 \mu \mathrm{Ci}$ & 6.2 & 2.4 & 3.5 & $1.48 / \prime$ & $0.62 \quad \prime \prime$ & $0.87 \quad \prime \prime$ \\
\hline 3 & 0 & 3 & $100 / /$ & $0.3 \prime \prime$ & 259 "I & 0.9 & 0 & 0.9 & $0.23 \quad$ II & $0 \prime \prime$ & $0.23 \quad 11$ \\
\hline 2 & 2 & 4 & $100 \prime \prime$ & $0.3 \prime \prime$ & $142 \prime \prime$ & 1.7 & 0.7 & 1.2 & $0.20 \prime \prime$ & $0.13 \quad \prime \prime$ & $0.16 \prime \prime$ \\
\hline 23 & 37 & 60 & $50 \prime \prime$ & $0.3 \prime \prime$ & $110 / /$ & 2.4 & 2.0 & 2.2 & $0.30 \quad \prime \prime$ & $0.20 \prime \prime$ & $0.24 \quad \prime \prime$ \\
\hline 12 & 16 & 28 & $100 \prime \prime$ & $3 \prime \prime$ & $2.05 \mathrm{mCi}$ & 10.2 & 4.3 & 6.9 & $20.40 \prime \prime$ & $9.21 \quad / \prime$ & $14.18 \prime \prime$ \\
\hline 45 & 98 & 143 & $2 \mathrm{mCi}$ & $15 \prime \prime$ & $7.33 \quad \prime \prime$ & 12.9 & 6.3 & 8.3 & $91.67 /$ & $47.01 / \prime$ & $61.05 / \prime$ \\
\hline 18 & 16 & 34 & $0.5 \prime \prime$ & $1 \prime \prime$ & $3.01 \quad \prime \prime$ & 6.7 & 5.6 & 5.2 & $17.44 \prime \prime$ & $20.14 \prime \prime$ & $18.70 / \prime$ \\
\hline 18 & 18 & 36 & $1 \prime \prime$ & $30 \prime \prime$ & $9.41 \quad / \prime$ & 7.7 & 3.9 & 5.8 & $88.96 \prime \prime$ & $33.84 \prime \prime$ & $61.40 \prime \prime$ \\
\hline 2 & 1 & 3 & $1 / \prime$ & & $1.39 / 1$ & 5.0 & 1.0 & 3.7 & $6.25 \prime \prime$ & $2.80 \quad \prime \prime$ & $5.10 \prime \prime$ \\
\hline 24 & 19 & 43 & $0.3 \prime \prime$ & $10 / \prime$ & $2.42 \quad \prime \prime$ & 15.0 & 6.6 & 11.3 & $38.09 / 1$ & $13.60 \prime \prime$ & $27.34 \prime \prime$ \\
\hline 9 & 5 & 14 & $3 \prime \prime$ & $10 / \prime$ & $9.41 \quad \prime \prime$ & 4.0 & 4.6 & 4.2 & $36.08 \prime \prime$ & $45.50 / /$ & $39.45 \prime \prime$ \\
\hline 8 & 2 & 10 & $2 \prime \prime$ & $10 / \prime$ & $6.42 \quad \prime \prime$ & 3.4 & 0.8 & 2.9 & $22.0 \quad 11$ & $3.75 \prime \prime$ & $18.35 / \prime$ \\
\hline 7 & 5 & 12 & $0.25 \quad$ II & $5 \prime \prime$ & $2.40 \quad \prime \prime$ & 0.8 & 1.6 & 1.2 & $1.81 / /$ & $3.92 \quad \prime$ & $2.93 \quad \prime \prime$ \\
\hline 1 & 2 & 3 & $3 \prime \prime$ & $10 \prime \prime$ & $3.75 \quad \prime \prime$ & 10.0 & 1.0 & 4.0 & $30.00 / \prime$ & $7.50 \quad \prime \prime$ & $15.00 / \prime$ \\
\hline 2 & 1 & 3 & $1 \prime \prime$ & $2 \prime \prime$ & $1.43 \prime \prime$ & 2.3 & 6.0 & 3.5 & $4.50 \prime \prime$ & $6.00 \prime \prime$ & $5.00 \quad \prime \prime$ \\
\hline 3 & 7 & 10 & $1 / \prime$ & $5 \prime \prime$ & $2.58 \quad \prime \prime$ & 6.3 & 9.3 & 8.4 & $30.00 / 1$ & $18.14 \prime \prime$ & $21.70 / 1$ \\
\hline 0 & 1 & 1 & $10 \prime \prime$ & $10 \prime \prime$ & $10.0 \quad \prime \prime$ & 0 & 5.0 & 5.0 & 0 & $50.00 \prime \prime$ & $50.00 \prime \prime$ \\
\hline 1 & 3 & 4 & $1.5 \prime \prime$ & $5 \prime \prime$ & $2.61 \quad \prime \prime$ & 20.0 & 2.3 & 6.8 & $60.00 / 1$ & $3.50 \prime \prime$ & $17.63 / \prime$ \\
\hline 3 & 7 & 10 & $2 \prime \prime$ & $15 \prime \prime$ & $10.53 \prime \prime$ & 13.3 & 13.9 & 13.7 & $116.67 \prime \prime$ & $156.00 \prime \prime$ & $144.20 / \prime$ \\
\hline 31 & 160 & 191 & $30 \mu \mathrm{Ci}$ & $200 \mu \mathrm{Ci}$ & $82 \mu \mathrm{Ci}$ & 37.1 & 17.9 & 20.9 & $2.78 \prime \prime$ & $1.53 / \prime$ & $1.72 /$ \\
\hline 17 & 20 & 37 & $7 \prime \prime$ & $100 \prime \prime$ & $29 \prime \prime$ & 46.8 & 59.8 & 53.8 & $1.46 \quad / \prime$ & $1.69 \prime \prime$ & $1.59 \prime \prime$ \\
\hline
\end{tabular}




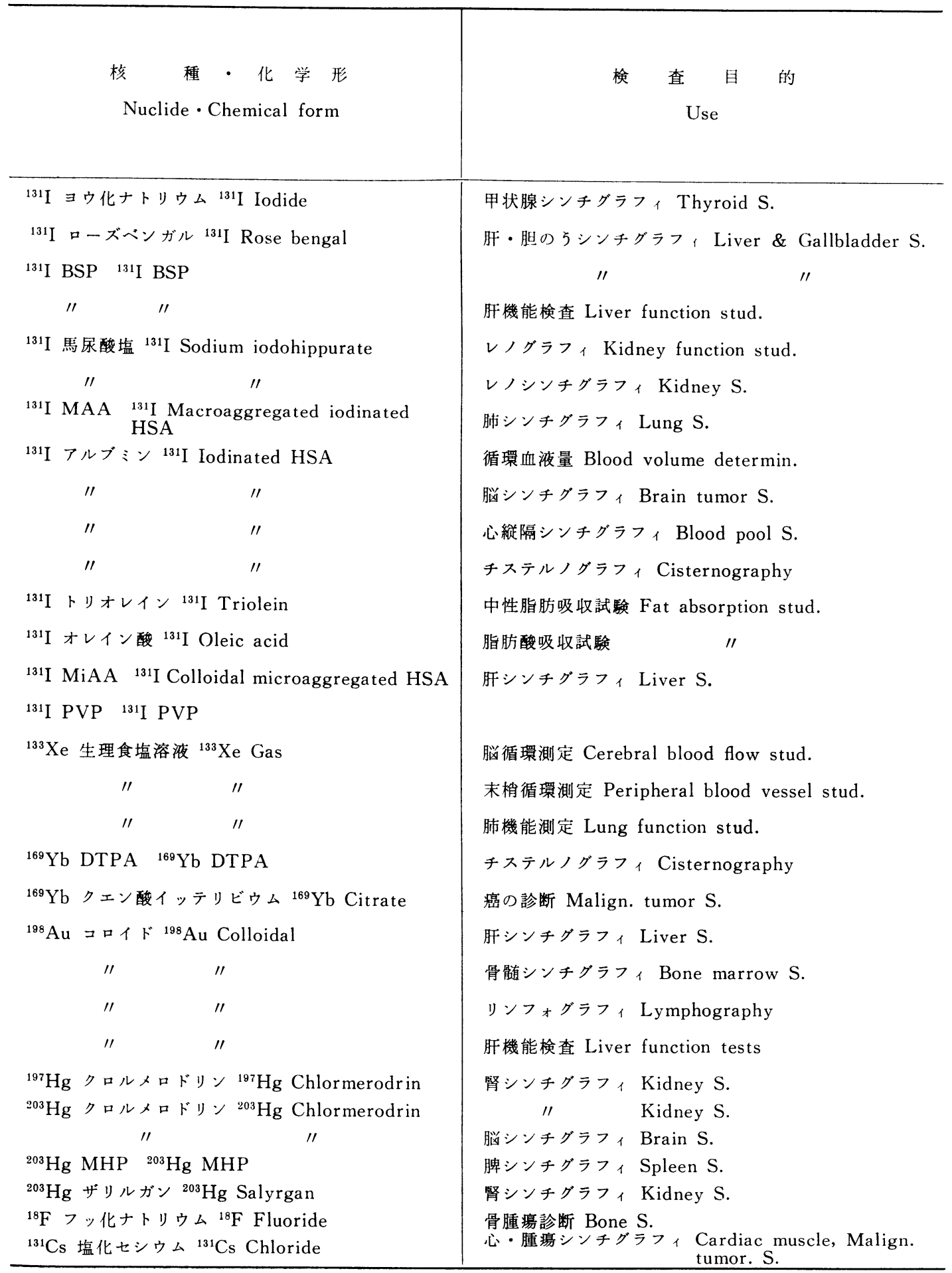




\begin{tabular}{|c|c|c|c|c|c|c|c|c|c|c|c|}
\hline \multicolumn{3}{|c|}{$\begin{array}{l}\text { 使 用 施 設 数 } \\
\text { Number of Facil. }\end{array}$} & \multicolumn{3}{|c|}{$\begin{array}{l}1 \text { 回投与量: }(\mu \mathrm{Ci}, \mathrm{mCi}) \\
\text { Administ'd doses/case }\end{array}$} & \multicolumn{3}{|c|}{$\begin{array}{l}1 \text { か月平均投与件数/施設 } \\
\text { Number of Cases/ } \\
\text { Facil. - month }\end{array}$} & \multicolumn{3}{|c|}{$\begin{array}{l}1 \text { か月平均投与量/施設 } \\
\text { Administ'd doses/ } \\
\text { Facil. • month }\end{array}$} \\
\hline $\begin{array}{l}\text { 大学病院 } \\
\text { Univ. } \\
\text { Hosp. }\end{array}$ & $\left|\begin{array}{c}\text { 一般病院 } \\
\text { o } \\
\text { Gen. } \\
\text { Hosp. \& } \\
\text { Other }\end{array}\right|$ & $\begin{array}{l}\text { 全 体 } \\
\text { Total }\end{array}$ & $\begin{array}{l}\text { 最 小 } \\
\text { Min. }\end{array}$ & $\begin{array}{l}\text { 最 大 } \\
\text { Max. }\end{array}$ & $\begin{array}{l}\text { 平均 } \\
\text { Mean }\end{array}$ & $\begin{array}{c}\text { 大学病院 } \\
\text { Univ. } \\
\text { Hosp. }\end{array}$ & $\mid \begin{array}{c}\text { 一般病院 } \\
\text { そ } \\
\text { Gen. } \\
\text { Hosp. \& } \\
\text { Other }\end{array}$ & $\begin{array}{l}\text { 全 体 } \\
\text { Total }\end{array}$ & \begin{tabular}{|l} 
大学病院 \\
Univ. \\
Hosp.
\end{tabular} & $\left|\begin{array}{c}\text { 一般病院 } \\
\text { そ } 9 \text { 他 } \\
\text { Gen. } \\
\text { Hosp. \& } \\
\text { Other }\end{array}\right|$ & $\begin{array}{l}\text { 全 体 } \\
\text { Total }\end{array}$ \\
\hline 17 & 28 & 45 & $25 \mu \mathrm{Ci}$ & $500 \mu \mathrm{Ci}$ & $\mathrm{i} \mid 135 \mu \mathrm{Ci}$ & 36.7 & 16.6 & 24.2 & $4.16 \mathrm{mCi} \mid$ & $2.70 \mathrm{mCi}$ & $\mathrm{i} 3.25 \mathrm{mCi}$ \\
\hline 24 & 51 & 75 & $40 \prime \prime \prime$ & $500 \prime \prime$ & 231 & 4.1 & 2.7 & 3.2 & $1.02 \quad /$ & $0.60 \quad \prime \prime$ & $0.73 \quad$ II \\
\hline 24 & 55 & 79 & $25 \prime \prime$ & $800 \prime \prime$ & $307 \prime \prime$ & 3.6 & 3.1 & 3.3 & 1.0611 & $0.97 \quad \prime \prime$ & $1.00 / 1$ \\
\hline 3 & 7 & 10 & $10 \prime \prime$ & $250 \prime \prime$ & $60 \prime \prime$ & 4.4 & 3.7 & 3.6 & $0.10 \quad / \prime$ & $0.27 \quad \prime \prime$ & $0.22 \quad \prime \prime$ \\
\hline 46 & 113 & 159 & $8 \prime \prime$ & $300 \prime \prime$ & $35 \prime \prime$ & 18.9 & 13.9 & 15.3 & $0.58 \quad$ " & $0.52 \quad$ II & $0.53 \prime \prime$ \\
\hline 5 & 7 & 12 & $100 \prime \prime$ & $300 \prime \prime$ & $223 \prime \prime$ & 5.6 & 14.7 & 10.9 & $1.03 / 1$ & $3.44 \prime \prime$ & 2.43 \\
\hline 47 & 118 & 165 & $100 \prime \prime$ & $1 \mathrm{mCi}$ & 250 & 9.3 & 4.0 & 5.5 & $2.23 \quad$ II & $1.04 \prime \prime$ & $1.38 / \prime$ \\
\hline 17 & 26 & 43 & $5 \prime \prime$ & $2 \prime \prime$ & $67 \prime \prime$ & 16.1 & 8.0 & 11.1 & $1.40 \quad / \prime$ & $0.34 \quad \prime \prime$ & $0.74 \quad \prime \prime$ \\
\hline 9 & 23 & 32 & $50 \prime \prime$ & $1 \prime \prime$ & $490 \prime \prime$ & 2.7 & 2.5 & 2.5 & $1.48 \quad$ " & 1.17 & 1.22 \\
\hline 5 & 12 & 17 & $150 /$ & $1 \prime \prime$ & $506 \prime \prime$ & 1.0 & 0.9 & 0.9 & $0.46 \quad / \prime$ & $0.47 \quad \prime \prime$ & $0.47 \quad$ II \\
\hline 3 & 7 & 10 & $100 \prime \prime$ & $250 \mu \mathrm{Ci}$ & 100 & 10.1 & 2.1 & 4.5 & $0.85 \prime \prime$ & $0.29 \quad / \prime$ & $0.46 \quad \prime \prime$ \\
\hline 26 & 30 & 56 & $5 \prime \prime$ & $200 \prime \prime$ & $81 \prime \prime$ & 4.7 & 2.6 & 3.6 & $0.36 \quad /$ & $0.22 \quad \prime \prime$ & $0.29 \quad \prime \prime$ \\
\hline 5 & 11 & 16 & $5 \prime \prime$ & $100 / 1$ & $74 \prime \prime$ & 2.2 & 3.4 & 3.0 & $0.11 \prime \prime$ & $0.27 \quad \prime \prime$ & $0.22 \quad \prime \prime$ \\
\hline 3 & 3 & 6 & $200 \prime \prime$ & $500 \prime \prime$ & $258 \prime \prime$ & 5.7 & 5.0 & 5.3 & $1.15 / /$ & $1.60 \prime \prime$ & $1.38 / /$ \\
\hline 3 & 4 & 7 & $20 \prime \prime$ & $100 / 1$ & $81 / \prime$ & 2.0 & 2.1 & 2.1 & $0.12 \quad \prime \prime$ & 0.20 & $0.17 \quad$ II \\
\hline 9 & 5 & 14 & $100 \prime \prime$ & $10 \mathrm{mCi}$ & $6.11 \mathrm{mCi}$ & 5.6 & 13.6 & 8.7 & $18.74 / \prime$ & $107.9 / \prime$ & $53.03 / \prime$ \\
\hline 6 & 3 & 9 & $10 \prime \prime$ & $2 \prime \prime$ & $1.49 \prime \prime$ & 8.8 & 11.7 & 9.8 & $13.47 \prime \prime$ & $16.67 / \prime$ & $14.53 \prime \prime$ \\
\hline 4 & 0 & 4 & $200 \prime \prime$ & $5 \prime \prime$ & $2.70 \quad \prime \prime$ & 1.8 & 0 & 1.8 & 4.90 & $0 \quad 11$ & 4.90 \\
\hline 24 & 21 & 45 & $300 \prime \prime$ & $1.5 \prime \prime$ & $769 \mu \mathrm{Ci}$ & 4.0 & 5.3 & 4.6 & $2.71 / l$ & 4.50 & $3.53 \prime \prime$ \\
\hline 2 & 0 & 2 & $500 \prime \prime$ & $1.0 \prime \prime$ & $638 \prime \prime$ & 8.0 & 0 & 8.0 & $5.10 \prime \prime$ & $0 \prime \prime \prime$ & 5.10 \\
\hline 48 & 183 & 231 & $70 \prime \prime$ & $0.6 \prime \prime$ & $252 \prime \prime$ & 35.8 & 20.1 & 23.4 & 7.89 & $5.38 \quad \prime \prime$ & $5.90 \quad / 1$ \\
\hline 3 & 3 & 6 & $200 \prime \prime$ & $2.01 \quad / \prime$ & $1.15 \mathrm{mCi}$ & 2.1 & 2.4 & 2.3 & $3.23 \quad 11$ & $2.00 \quad / 1$ & $2.62 \quad$ II \\
\hline 3 & 4 & 7 & $100 \prime \prime$ & $0.5 \prime \prime$ & 219 II & 2.1 & 3.0 & 2.6 & 0.43 & $0.68 \quad \prime \prime$ & $0.57 \prime \prime$ \\
\hline 1 & 1 & 2 & $100 / 1$ & $200 \mu \mathrm{Ci}$ & 183 & 1.0 & 5.0 & 3.0 & $0.10 / 1$ & $1.00 / /$ & $0.55 \quad \prime \prime$ \\
\hline 3 & 9 & 12 & $100 / 1$ & $1 \mathrm{mCi}$ & $540 \prime \prime$ & 13.0 & 7.2 & 8.6 & $5.42 \quad \prime$ & 4.60 & $4.65 \prime \prime \prime$ \\
\hline 41 & 122 & 163 & $50 / /$ & $0.5 \prime \prime$ & $200 \prime \prime$ & 7.8 & 3.2 & 4. 4 & $1.42 \quad \prime$ & $0.69 \prime \prime \prime$ & $0.87 \quad \prime \prime$ \\
\hline 3 & 5 & 8 & $200 \prime \prime$ & 111 & $546 \prime \prime$ & 3.9 & 1.7 & 2.9 & $2.30 \quad \prime \prime$ & $0.84 \quad \prime \prime$ & 1.58 \\
\hline 27 & 42 & 69 & $100 / /$ & $0.5 \prime \prime$ & $174 \prime \prime$ & 3.2 & 1.8 & 2.3 & $0.46 \quad \prime \prime$ & $0.37 \quad /$ & $0.40 \quad \prime \prime$ \\
\hline 3 & 1 & 4 & 80 "I & $200 \mu \mathrm{Ci}$ & $129 / \prime$ & 4.6 & 4.0 & 4.4 & $0.63 \prime$ & $0.40 \quad / /$ & $0.57 \quad \prime \prime$ \\
\hline 1 & 1 & 2 & $1 \mathrm{mCi}$ & $2 \mathrm{mCi}$ & $1.33 /$ & 1.0 & 2.0 & 1.5 & $2.00 \prime \prime$ & $2.00 \quad / 1$ & $2.00 \quad 11$ \\
\hline 4 & 4 & 8 & $100 \mu \mathrm{Ci}$ & $1 / \prime$ & $791 \mu \mathrm{Ci} \|$ & 1.0 & 0.7 & 0.8 & $0.94 \quad 1$ & $0.44 \quad \prime \prime$ & $0.69 \prime \prime \prime$ \\
\hline
\end{tabular}


Table 9 Details of radioisotope

\begin{tabular}{|c|c|}
\hline $\begin{array}{l}\text { 核 喠 } ・ \text { 化 学 形 } \\
\text { Nuclide } \cdot \text { Chemical form }\end{array}$ & $\begin{array}{l}\text { 療 } \\
\text { Use }\end{array}$ \\
\hline $\begin{array}{l}{ }^{32} \mathrm{P} \text { リン酸ナトリウム }{ }^{32} \mathrm{P} \text { Soluble phosphate } \\
{ }^{131} \mathrm{I} \text { ヨウ化ナトリウム }{ }^{131} \mathrm{I} \text { Iodide } \\
{ }^{198} \mathrm{Au} \text { コロイド }{ }^{198} \mathrm{Au} \text { Colloidal } \\
\quad "\end{array}$ & $\begin{array}{l}\text { 真性多血症・慢性白血病 } \mathrm{T} .^{*} \text { of polycythemia vera } \\
\text { and leukemia } \\
\text { 甲状腺機能六進症 } \mathrm{T} \text {. of Hyperthyroidism } \\
\text { 甲状腺癌 } \mathrm{T} \text {. of thyroid carcinoma } \\
\text { 癌性漿膜炎 Intracavitary t. of pleural effusions } \\
\text { and ascites } \\
\text { 関節リウマチ } \mathrm{T} \text {. of Rheumatism }\end{array}$ \\
\hline
\end{tabular}

* T.: Treatment

は妥当な結果のように思われる。最後に各検査が 1 施 設当り 1 か月にどの程度行なわれているかその平均投 与件数, 平均投与量をまとめた。使用している施設で の平均として算出した結果を表 $8 ， 9$ 亿示すが全体と してみた場合，1か月に15件以上の投与件数を示す検 查はわずかで, ${ }^{131} \mathrm{I}$-ヨウ化ナトリウムによる甲状腺機 能検查関係, ${ }^{131} \mathrm{I}$-馬尿酸塩によるレノグラフィ, そし て ${ }^{198} \mathrm{Au}$-コロイドによる肝シンチグラフィの 3 種に 過ぎない。過半数 (40種) の検査は 1 か月平均 5 件以 下で変化に富んでいることが伺われる。また，平均投 与量はやはり短半減期アイソトープの ${ }^{99 m} \mathrm{Tc},{ }^{113 m} \mathrm{In}$, そして ${ }^{133} \mathrm{Xe}$ によるものが圧倒的に高くこの 3 核種 を除くと, ${ }^{87 m} \mathrm{Sr},{ }^{67} \mathrm{Ga}$ などが比較的投与量の多い結 果を示している。

\section{3. 総 括}

今回のアンケート調査について 270 施設の集計結果 を要約すると次のと扔りである。

1)体内投与件数は 1 施設当りで比較した場合, 1968 年の約 2 倍 $(1,066$ 件/年) 飞増加している。また診断 之治療の別では診断件数の比率が圧倒的に高く（97.6 $\%$ ，治療件数は $2.4 \%$ に過ぎない。検查・・診断に利用 される核種は依然 ${ }^{131} \mathrm{I}$ が最も多く, 全件数の $50 \%$ をし めている。 ${ }^{131} \mathrm{I}$ に次いで利用されている核種は ${ }^{198} \mathrm{Au}$ コロイド $(22.5 \%)$ である。1968年に比べ今回はさら 飞 ${ }^{99 m} \mathrm{Tc},{ }^{75} \mathrm{Se},{ }^{67} \mathrm{Ga}$ の利用が增大している。

2)体内投与量は 1 施設当り平均 $1,240 \mathrm{mCi} /$ 年使用し ており，1968年の 2.3 倍増であった。診断と治療の比
率は $1: 0.4$ と量的にも診断は治療を上まわっている。 核種では ${ }^{99 m} \mathrm{~T} \mathrm{c}$ が50\%近い量をしめている。一方 ${ }^{131} \mathrm{I}$ はわずかずつ増加しているが全使用量に対する割合は 年々減少の傾向にある。

3)わが国の過半数の施設で行なわれているアイソト ープ検査は ${ }^{198} \mathrm{Au}$-コロイドによる肝シンチグラフィ （全施設に対する使用施設頻度は $85.6 \%$ )， ${ }^{131} \mathrm{I}$ による 甲状腺機能検查 $(70.7 \%),{ }^{131} \mathrm{I}$-MAA による肺シン チグラフィ(61.1\%)， ${ }^{203} \mathrm{Hg}$ クロルメロドリンによ る腎シンチグラフ $(60.4 \%),{ }^{131} \mathrm{I}$-馬尿酸塩による レノグラフィ(58.9\%) および ${ }^{99 m} \mathrm{~T} \mathrm{c}$-過テクネチウ ム酸塩による脳シンチグラフィ（53\%）の以上 7 種で ある。また， 1 回の検査で患者に投与されるアイソト ープ量はかなりの幅がみられた。

以上のうち 1 施設当り 1 か月平均 15 件以上の投与件 数を示す検査は甲状腺機能検査, レノグラフィ, 肝シ ンチグラフィの 3 種に過ぎない。過半数は 1 か月平均 5 件以下である。また平均投与量では ${ }^{99 m} \mathrm{Tc},{ }^{113 m} \mathrm{In}$, そして ${ }^{133} \mathrm{Xe}$ を用いた場合が圧倒的に高く，次いで ${ }^{87 m} \mathrm{Sr},{ }^{67} \mathrm{Ga}$ が挙げられる。

\section{4. おわりに}

今回のアンケート調査は回収率 $60 \%$ とやや低かった が，以上の集計結果からわが国核医学診療に使用され ている体内投与アイントープの現状の概略を把握でき ると思う。1965年, 1968年の過去 2 回の統計と今回の 統計を比較した結果明らかなように, 投与件数, 投与 量ともに着実な伸びを示しており，わが国のアイント 
の使用内訳 (治 療)

applications used for treatments

\begin{tabular}{|c|c|c|c|c|c|c|c|c|c|c|c|}
\hline \multicolumn{3}{|c|}{$\begin{array}{l}\text { 使 用 施 設 数 } \\
\text { Number of Facil. }\end{array}$} & \multicolumn{3}{|c|}{$\begin{array}{l}1 \text { 回投与量 }(\mu \mathrm{Ci}, \mathrm{mCi}) \\
\text { Administ'd doses/case }\end{array}$} & \multicolumn{3}{|c|}{$\begin{array}{l}1 \text { か月平均投与件数/施設 } \\
\text { Number of Cases/ } \\
\text { Facil. } \cdot \text { month }\end{array}$} & \multicolumn{3}{|c|}{$\begin{array}{l}1 \text { か月平均投与量/施設 } \\
\text { Administ'd doses/ } \\
\text { Facil. ・ month }\end{array}$} \\
\hline $\begin{array}{c}\text { 大学病院 } \\
\text { Univ. } \\
\text { Hosp. }\end{array}$ & $\mid \begin{array}{cc}\text { 一般病院 } \\
\text { そ } \\
\text { G } \\
\text { Gen. } \\
\text { Hosp. \& } \\
\text { Other }\end{array}$ & $\begin{array}{l}\text { 全 体 } \\
\text { Total }\end{array}$ & $\begin{array}{l}\text { 最小 } \\
\text { min. }\end{array}$ & $\begin{array}{l}\text { 最 大 } \\
\max \text {. }\end{array}$ & $\begin{array}{l}\text { 平均 } \\
\text { mean }\end{array}$ & $\begin{array}{c}\text { 大学病院 } \\
\text { Univ. } \\
\text { Hosp. }\end{array}$ & $\mid$\begin{tabular}{|c|} 
般病院 \\
そ \\
Gen. \\
Hosp. \& \\
Other
\end{tabular} & $\begin{array}{l}\text { 全 体 } \\
\text { Total }\end{array}$ & $\begin{array}{c}\text { 大学病院 } \\
\text { Univ. } \\
\text { Hosp. }\end{array}$ & $\left|\begin{array}{c}\text { 一般病院 } \\
\text { そ } \\
\text { Gen. } \\
\text { Hosp. \& } \\
\text { Other }\end{array}\right|$ & $\begin{array}{l}\text { 全 体 } \\
\text { Total }\end{array}$ \\
\hline 2 & 6 & 8 & $3^{\mathrm{mCi}}$ & $5^{\mathrm{mCi}}$ & $\begin{array}{l}\mathrm{mCi}^{\mathrm{m}} \\
3.76\end{array}$ & 1.7 & 1.0 & 1.2 & $\mathrm{mCi}_{6.75}$ & 3.58 & $4.38^{\mathrm{mCi}}$ \\
\hline 40 & 76 & 116 & 2 & 20 & 4.77 & 3.3 & 4.8 & 4.3 & 16.26 & 22.50 & 20.29 \\
\hline 6 & 5 & 11 & 10 & 100 & 57.19 & 0.6 & 1.0 & 0.8 & 34.17 & 59.00 & 44.10 \\
\hline 23 & 38 & 61 & 5 & 100 & 62.63 & 1.6 & 1.1 & 1.2 & 84.60 & 74.06 & 78.09 \\
\hline 2 & 0 & 2 & 4 & 5 & 4.75 & 2.0 & 0 & 2.0 & 9.50 & 0 & 9.50 \\
\hline
\end{tabular}

ープ診療が確実な基盤をもっていることはご同慶の至 りである。今後, どの程度伸展があるか予測はむずか しいが，現状よりさらに発展することは疑う余地がな く,アイソトープ診療に適した新しい核種，標識化合 物の開発がよりいっそう望まれる。

本アンケート調査にご協力いただいた多くの診療機 関の関係各位に厚く和礼申上げるとともに，RI を使 用している診療機関名簿をご提供下さった日本アイソ トープ協会, ご協力いただいた千葉大学放射線科諸兄 姉に謝意を表します。

\section{文献}

1）筧 弘毅，他：日本に打ける核医学診療の現況 (1972年), I . 検査機器の利用について, Radioisotopes, 22, 215 19 (1973)

2）筧 弘毅，他：日本に和ける核医学診療の現況 (1972年), II. In vitro tests について, Radioisotopes, 22, 534 38 (1973)

3）筧 弘毅：わが国核医学に利用するアイントー プの現況, Radioisotopes, 19, 102〜07 (1970) 